\title{
Strategy for Benefiting the Bt Cotton Growers of Nagpur District of Maharashtra, India
}

\author{
L. Raja $^{1^{*}}$ and V.S. Tekale ${ }^{2}$ \\ ${ }^{1}$ Division of Dairy Extension, NDRI, Karnal - 132001, India \\ ${ }^{2}$ Department of Extension Education, College of Agriculture, Nagpur - 440001, India \\ *Corresponding author
}

\section{A B S T R A C T}

Keywords

Strategy, Training,

Tobacco streak

virus, Private

companies, Inputs,

Spurious seed.

Article Info

Accepted:

23 May 2017

Available Online:

10 June 2017
The present study reports suitable strategy for benefiting the Bt- cotton growers and it was conducted in Nagpur District of Maharashtra in the year 2014-2016 with $120 \mathrm{Bt}$ cotton growers. Strategy designed for benefiting Bt cotton growers depicts- Creating awareness on purchase of Bt cotton seed only from standard and licensed companies, more number of trainings to be given on adoption gaps in $\mathrm{Bt}$ cotton such as cultivation of refugee rows, selection of soil types and fertilizer use etc, development of specific packages for management of newly emerging pest and diseases like pink boll warm, tobacco streak virus, cucumber mosaic virus, mealy bugs, grey mildew and wilt, continuous efforts are necessary to evolve sucking pests and drought resistant varieties in Bt cotton, increasing inspection and ride on the private companies well in advance before sale of the seeds and fertilizers instead of taking action after the inputs are sold and stringent measures to curb the spurious seed selling and illegal companies in the market.

\section{Introduction}

India continued to maintain the rank of second largest producer of cotton next to china. USA and India export around 28 and 20 per cent of the world cotton exports and china will be the major importer in the world. Around 48 per cent of the total cotton (18.5 million bales of $480 \mathrm{~kg}$ ) import will be to China. Among the major cotton growing countries, Australia tops with the productivity level of $1804 \mathrm{~kg} / \mathrm{ha}$ followed by Brazil (1446 $\mathrm{kg} / \mathrm{ha}$ ) and China (1326 kg/ha) (United States Department of Agriculture, Foreign Agricultural Service, 2012). Cotton occupies a place of pride being the prime supplier of raw material $(85.00 \%)$ for textile industry, which is one of the leading industries in the country. Cotton industries provide means of livelihood for about 250 million people through its cultivation, trade and industries in India (Cotton Advisory Board, 2012). Cotton occupies a predominant place among cash crops touching the India's economy at several points by generating direct and indirect employment in the agricultural and industrial sectors.

A loss of US $\$ 1.0$ billion worth cotton has been accounted for a single dreaded pest, $H$. armigera every year (Gujar et al., 2000). Bollworm control takes a heavy toll up to Rs. 
1,200 crores in a year by Indian farming community (Kannan, 2004). The intensive (and extensive too) investment on insecticides to get rid of bollworms could not pay due dividend for longer time. The sole reliance on synthetic insecticides created significant agroecological problems like resurgence and insecticide resistance pushing cotton cultivation to cross roads. Based on the demand for technical solution to the quite intense bollworm problem in cotton in India, the country resorted for adoption of $B t$ transgenic cultivars with approval of GEAC (Genetic Engineering Approval Committee) of Department of Biotechnology, Govt. of India on March 26, 2002. Aundhakar (2013) reported the suggestions which are invited from orange growers are provide information about application of water soluble fertilizers, chemical treatment to avoid chocking of drippers, increase the subsidy and facility on drip irrigation by government and training should be provided on installation of drip unit.

Dongre (2014) concluded that, majority of soya bean growers suggested that credit should be provided in time with lower rate of interest by cooperative banks and village institutions, chemical fertilizers and pesticides should be available at proper time with minimum price. Madanmohan Reddy (2014) formulated strategy for efficient soyabean production were research need to be conducted to breed the varieties suitable for Rabi season, more awareness programmes have to be conducted to empower the people on benefits of soya products there by increasing the cultivable area and net returns to the farmers and more processing industries should be established to generate value added products from soya produce.

\section{Materials and Methods}

Exploratory research design was used in the present investigation. The study was conducted in Nagpur district of Maharashtra, from the selected district two tahsils were selected purposively based on highest area under $\mathrm{Bt}$ cotton cultivation and from each selected tahsils, six villages were selected randomly, 10 respondent Bt-cotton growers were selected randomly from each village making total 120 respondents. After finding the constraints faced by Bt cotton growers, suitable strategy are formulated for benefiting the Bt cotton growers.

\section{Results and Discussion}

While conducting this research the researcher interacted with $B t$ cotton growers, cotton scientists and extension functionaries. The suitable strategies formulated by the researcher for benefiting $B t$ cotton growers were listed in three sub headings i.e. strategies for extension functionaries, for researcher and government.

\section{Strategies for extension functionaries}

Creating awareness on purchase of $B t$ cotton seed only from standard and licensed companies.

More number of trainings to be given on adoption gaps in $B t$ cotton such as cultivation of refugee rows, selection of soil types and fertilizer use etc.

In order to promote farmer led extension, progressive farmers groups of $B t$ cotton cultivation may be identified at village, tahsil, districts and state level.

They should be trained on $B t$ cotton cultivation. These trained farmers would be used as resource persons in extension activities.

Creating awareness to farmers and extension workers on insecticide resistance management 
strategies (including with cowpea and blackgram, avoiding chlorothalonil and organic pesticides sprays for sucking pest control, soil application of dimethoate/acephate at 30-40 DAS and 50-60 DAS for control of sucking pests) use of $\mathrm{Ha}$ $\mathrm{NPV}$, not to spray $B t$ formulation and spinosad in Bt cotton (Singh, et al., 2011).

More extension efforts on INM, IPM, maintenance of refuge crop, water management, value addition, mechanization, crop insurance, marketing, weather based forecasting, pros and cons of GM Crops, credit management are to be intensified.

\section{Strategies for researcher}

Development of specific packages for management of newly emerging pest and diseases like pink boll warm tobacco streak virus, cucumber mosaic virus, mealy bugs, grey mildew and wilt.

Development and commercialisation of $B t$ cotton hybrids by public sector is the need of hour which avoids complete dependency on private companies. Continuous efforts are necessary to evolve sucking pests and drought resistant varieties in $B t$ cotton.

Human labour being the major cost item in cotton cultivation, so, efforts should be made to mechanize field operations of $B t$ cotton cultivation.

Development of appropriate machinery and implements for different operations including cotton picking, fertilizers and pesticides application was urgently needed.

\section{Strategies for government}

Increasing inspection and ride on the private companies well in advance before sale of the seeds and fertilizers instead of taking action after the inputs are sold.

Increased vigilance on small companies doing co marketing.

Stringent measures to curb the spurious seed selling and illegal companies in the market.

Constructive steps to regulate fluctuations in market prices.

Stringent measures on the dealers and companies and cancelation of licences and imprisonments should be done on those selling spurious seed or high cost seed.

It could be concluded from the study the important strategy for benefiting the Bt cotton growers were- Creating awareness on purchase of $B t$ cotton seed only from standard and licensed companies, more number of trainings to be given on adoption gaps in $B t$ cotton such as cultivation of refugee rows, selection of soil types and fertilizer use etc, more extension efforts on INM, IPM, maintenance of refuge crop, water management, value addition, mechanization, crop insurance, marketing, weather based forecasting, pros and cons of GM Crops, credit management are to be intensified, development of specific packages for management of newly emerging pest and diseases like pink boll warm tobacco streak virus, cucumber mosaic virus, mealy bugs, grey mildew and wilt, continuous efforts are necessary to evolve sucking pests and drought resistant varieties in $B t$ cotton, increasing inspection and ride on the private companies well in advance before sale of the seeds and fertilizers instead of taking action after the inputs are sold, stringent measures to curb the spurious seed selling and illegal companies in the market and constructive steps to regulate fluctuations in market prices. 


\section{References}

Aundhakar, R. S. 2013. Adaption of drip irrigation technologies by the orange growers. M.Sc. (Agri.) Thesis (unpub.) Dr. PDKV, Akola.

Cotton Advisory Board, 2012 www.cotcorp.gov.in

Dongre, R. H. 2014. Knowledge and adaption of production technologies by soya bean growers. M.Sc. (Agri.) Thesis (unpub.) Dr. PDKV, Akola.

Gujar, G. T., K. V. Archana Kumari and V. Chandra Shekar, 2000. Spatial and temporal variation in susceptibility of American bollworm, Helicoverpa armigera (Hubner) to Bacillus thuringiensis var. kurstaki. Current Sci, 78: 995-1001.

Kannan, M. 2004. Studies on geographical variation and susceptibility of Helicoverpa armigera (Hubner) to transgenic cotton. Ph.D. Thesis (unpub.) Tamil Nadu Agric. Univ., Coimbatore, India.

Madanmohan Reddy, K. 2014. SWOT analysis of soyabean production. M.Sc. (Agri.) Thesis (unpub.) Acharya N.G. Ranga Agricultural University, Hyderabad, India.

Singh, T. V. K., N. V. V. S. D. Prasad, S. Sharma and S. Dayakar, 2011. Impact of IRM strategies on $B t$ cotton in Andhra Pradesh. Acharya N.G Ranga Agricultural University, Hyderabad, India. https://www.icac.org.

United States Department of Agriculture, Foreign Agricultural Service, 2012 http://aiccip.cicr.org.in

\section{How to cite this article:}

Raja, L., and Tekale, V.S. 2017. Strategy for Benefiting the Bt Cotton Growers of Nagpur District of Maharashtra. Int.J.Curr.Microbiol.App.Sci. 6(6): 2026-2029. doi: https://doi.org/10.20546/ijcmas.2017.606.238 